\title{
Overview of Domestic and Agricultural Pesticides Use Contributing to Aedes aegypti Resistence in Ambarawa Subdistrict, Indonesia
}

\author{
Arniyati Versari $^{1 \otimes}$, Dyah Mahendrasari Sukendra ${ }^{2}$, Shobiechah Aldillah Wu- \\ landhari ${ }^{3}$
}

1,2Public Health Department, Universitas Negeri Semarang, Indonesia

${ }^{3}$ Department of Medical Entomology, Faculty of Tropical Medicine, Mahidol University, Thailand

\begin{tabular}{l} 
Article Info \\
\hline Article History: \\
Submitted July 2020 \\
Accepted September 2020 \\
Published January 2021 \\
\hline Keywords: \\
Behaviour, household insecticide, \\
agricultural insecticide, \\
resistancey \\
\hline DOI \\
https://doi.org/10.15294/ \\
ujph.v10i1.39923 \\
\hline
\end{tabular}

\begin{abstract}
Ambarawa Sub District Semarang District is an endemic area of DHF. Furthermore, the year 2019 recorded an increase in the IR and CFR by 271.73, and 1.123\% respectively. Insecticide resistance contributed to the increase in DHF cases. Therefore, this study aims to determine the description of community behavior concerning the use of household and agricultural insecticide which lead to insecticide resistance in Aedes aegypti. This type of research is descriptive using qualitative methods. The informants are insecticide users in Ambarawa subdistrict. Twenty-four sample is choosen by purposive sampling. In-depth interview is carried out for the data collection. Data analysis used is data reduction, data presentation, and data verification using the manual way. As the result of the study, most of the subjects experienced a decrease in the effectiveness of insecticides, caused by poor community knowledge, and behavior of people who did not apply any insecticide resistance management guidelines. Considering the condition of current insecticide circulation, the government needs to make policies relating to the management of insecticide resistance.
\end{abstract}

$26.12 / 100,000$ population.

\section{INTRODUCTION}

Dengue Haemorrhagic Fever (DHF) is a public health problem in Indonesia that has not been resolved until now, throughout the year there are always quite high cases, especially during the rainy season (Data Center and Information from the Ministry of Health of the Republic of Indonesia, 2017). Globally recorded in WHO (2012) there are 3.9 billion world population at risk of dengue infection, and among them there are 128 tropical and subtropical countries at risk with 96 million cases. Based on data from the Indonesian Ministry of Health in 2017, the number of DHF cases in Indonesia was reported as many as 68,407 cases with the number of cases dying as many as 493 people, and IR (incidence rate)
The incidence rate (IR) of DHF in Central Java Province based on the Central Java Provincial Health Office in 2017 was 21.68 / 100,000 population, then decreased in 2018 to 8.68 / 100,000 population, and increased again in January 2019 as many as 1,204 cases. Ambarawa district is one of the endemic areas of DHF in Semarang Regency. In 2017 there were 55 cases of DHF with a CFR of 0.8 , and a decrease with 28 cases and 1 death in 2018, with an IR of 85.49, and a CFR of $3.571 \%$. Then in 2019 there was an increase, namely IR 271.73, and CFR 1,123\%.

$\mathrm{DHF}$ vector control can be carried out by physical control, biological control and chemical control, chemical control is the last choice in vec-

\footnotetext{
Correspondence Address:

Public Health Department, Universitas Negeri Semarang, F5 Building, Floor 2,

Sekaran, Gunungpati, Semarang, Indonesia, 50229

E-mail: arni.versari@gmail.com 
tor control because of its huge impact, but chemical control remains the main tool in mosquito control (Gatton et al., 2013). In addition, most people also ignore instructions for proper insecticide use, which can lead to vector resistance to insecticides (Joharina \& Alfiah, 2012; Sunaryo, 2015). The development and spread of insecticide resistance is a serious threat because it can cause a decrease in the effectiveness of larvicide-based control programs, as aimed at the main vector causing DHF, namely Aedes aegypti (Farajollahi et al., 2014). Ae. aegypti mosquito resistance to insecticides has been reported in various countries (Chareonviriyaphap et al., 2013). The results of Widiarti's (2015) research in Central Java showed that the Ae. aegypti mosquito had resistance to the insecticides malathion $0.8 \%$, permethrin $0.75 \%$, deltamethrin $0.05 \%$, etophenprok $0.5 \%$, and bendiokarb $0.1 \%$. Based on the results of research conducted by Cahyati \& Fitriani (2020), it shows that in Kupang village, Panjang village and Tambakboyo Village in Ambarawa District, Semarang Regency, 27 out of 30 Ae. aegypti respondents detected resistance to the insecticide cypermethrin. Resistance occurs in the VGSC gene at codon V1016G.

The use of household insecticides among the community is currently increasing, where the use of insecticides is the highest proportion of efforts to control mosquito vectors compared to other efforts. The increasing use of chemical insecticides has caused anxiety among the public because insecticides can have a negative impact on humans, mosquito vectors, and the environment. The behaviour of using household insecticides is inappropriate, especially in densely populated areas and in an environment suitable for mosquito habitat. The suitable mosquito habitat results in a high mosquito population, this can affect residents in the use of household insecticides, which tend to increase and even do not comply with insecticide use regulations. The use of insecticides is associated with an increase in the susceptibility status of Ae. aegypti mosquitoes, which is a factor causing resistance (Gaton et al., 2013; Riyadi, 2017; Pinto et al, 2019; Kusumawati \& Sukendra, 2020). The results of research by Mathieu et al. (2012) there is resistance thought to be caused by the behaviour of household use of insecticides, namely the duration of use of household insecticide 2-3 years with the same type of insecticide and continuous application.

Until now, most farmers in Indonesia still depend on the use of chemical insecticides to control insects in agriculture. Use according to the rules and in the right way is an absolute thing that must be done. The results of Widiarti's (2015) study regarding the use of pesticides from the agricultural sector, the use of insecticides in agriculture that is not appropriate can affect the rate at which resistance occurs in mosquito vectors. Resistance can occur due to the use of insecticides 4-5 times per year, with insecticides that have the same method of action, and with inappropriate doses. The results of research by Matowo et al. (2020) also show that farmers use pesticides according to their wishes, even increasing the dosage in the hope that it can kill pests maximally without knowing if the use of pesticides that is not appropriate can make the vector resistance to insecticides. Improper use of pesticides, especially in overuse over large areas and lots of vegetation, carries a high risk of resistance. Areas with high and dense vegetation can be a good habitat for mosquitoes to breed. Sometimes this triggers people to use insecticides excessively. Ae. aegypti resistance is also supported by a poor vector control program, namely fogging, a high fogging frequency of about 3 times / year, the application of chemical insecticides for a period of more than 5 years, and the use of insecticides that are not according to the dose can trigger resistance (Sukendra et al., 2020).

This study aims to determine the supporting factors for household and agricultural insecticide resistance to Aedes aegypti in Ambarawa District. The results of this study can contribute to policy making regarding the prevention of $\mathrm{Ae}$ des aegypti resistance with the aim of reducing DHF cases.

\section{METHODS}

This type of research is descriptive using quantitative methods. Respondents in this study were the general public and farmers, totaling 12 household insecticide users and 12 agricultural insecticide users. Determination of respondents in this study using purposive sampling technique with a total of 24 respondents.

Respondents of this research live in $\mathrm{Ku}$ pang village, Tambakboyo village, and Panjang village, Ambarawa district. The inclusion criteria for general public respondents determined by the researchers were household insecticide users of the type of sipermethrin and deltamethrin, aged 20-60 years, DHF sufferers or neighbors who are from home to DHF sufferers with a radius of $100 \mathrm{~m}$. For farmer respondents, inclusion criteria were applied in the form of cultivators and owners who manage rice fields with a maximum distance of $100 \mathrm{~m}$ from DHF sufferers, farmers who use agricultural insecticides of the type of siper- 
methrin, permethrin, deltamethrin, and carbosulfan, DHF sufferers or neighbors who are from home to DHF sufferers with radius $100 \mathrm{~m}$. The exclusion criteria for general public respondents were agricultural insecticide users. The exclusion criteria for farmer community respondents with the exclusion criteria are household insecticide users.

Data collection was carried out by interview referring to the resistance management manual issued by the Ministry of Health in 2012. The research instruments used in data collection were interview guidelines, recording devices, and field notes. Data analysis techniques in this study used data collection, data reduction, data presentation and data verification (Sugiyono, 2016).

\section{RESULTS AND DISCUSSION}

Based on the research results, it can be seen that the characteristics of the research area are based on knowledge, attitudes, and actions of using insecticides that support the incidence of Ae. aegypti resistance. The research area was carried out in DHF endemic areas in Ambarawa District, consisting of 3 villages in Ambarawa District, namely, Kupang Village, Panjang Village, and Tambakboyo Village.

The results of the research for the criteria for the characteristics of the respondents in the general population of household insecticide users, namely the age range of 20-30 years, dominated the research respondents, namely $58 \%, 67 \%$ of the last education was Senior High School, $33 \%$ of household income was between 2,500,100-3,500,000. Respondents of farmer research, namely the age range of $41-50$ years, dominate the respondents of farmer research, namely $50 \%, 42 \%$ of the latest education is Senior High School, $82 \%$ of household income is mostly between $1,500,100-3,500,000$, and $50 \%$ of farming time is around $10-20$ years, and $50 \%$ more than 20 years.

Table 1. Respondent Characteristics Frequency Distribution

\begin{tabular}{|c|c|c|c|}
\hline No. & Respondent Characteristics & Frequency & Percentage (\%) \\
\hline 1. & $\begin{array}{l}\text { Age Range } \\
\text { General public } \\
31-40 \\
41-50 \\
51-60 \\
\text { Farmers } \\
31-40 \\
41-50 \\
51-60\end{array}$ & $\begin{array}{l}7 \\
3 \\
2 \\
2 \\
6 \\
4\end{array}$ & $\begin{array}{l}58 \\
25 \\
17 \\
\\
17 \\
50 \\
33\end{array}$ \\
\hline 2. & $\begin{array}{l}\text { Latest Education } \\
\text { General public } \\
\text { Elementary school } \\
\text { Junior High School } \\
\text { Senior High School } \\
\text { University } \\
\text { Farmers } \\
\text { Elementary school } \\
\text { Junior High School } \\
\text { Senior High School } \\
\text { University }\end{array}$ & $\begin{array}{l}1 \\
2 \\
8 \\
1 \\
\\
2 \\
4 \\
5 \\
1\end{array}$ & $\begin{array}{l}8 \\
17 \\
67 \\
8 \\
\\
17 \\
33 \\
42 \\
8\end{array}$ \\
\hline 3. & $\begin{array}{l}\text { Household Income } \\
\text { General public } \\
500.100-1.500 .000 \\
1.500 .100-2.500 .000 \\
2.500 .100-3.500 .000 \\
3.500 .100-4.500 .00 \\
<4.500 .000 \\
\text { Farmers } \\
500.100-1.500 .000 \\
1.500 .100-2.500 .000 \\
2.500 .100-3.500 .000\end{array}$ & $\begin{array}{l}1 \\
3 \\
4 \\
2 \\
2 \\
\\
5 \\
5 \\
2\end{array}$ & $\begin{array}{l}8 \\
25 \\
33 \\
17 \\
17 \\
\\
41,5 \\
41,5 \\
17\end{array}$ \\
\hline 4. & $\begin{array}{l}\text { Length of farming time } \\
10-20 \text { years } \\
<20 \text { years }\end{array}$ & $\begin{array}{l}6 \\
6\end{array}$ & $\begin{array}{l}50 \\
50\end{array}$ \\
\hline
\end{tabular}


Public Knowledge about Insecticide Management

The results of the research regarding the level of knowledge of the research subjects of the household insecticide user community, namely, $42 \%$ of the subjects had knowledge related to the understanding of insecticide resistance. Answers to the interview results with the following details $42 \%$ of subjects knew the signs of resistance, all subjects $(0 \%)$ could not correctly answer the causes of resistance, $17 \%$ of subjects knew how to prevent resistance, $33 \%$ of subjects knew the impact of using inappropriate insecticides, all subjects $(0 \%)$ could not answer correctly how to overcome insecticide resistance, and no subjects had knowledge of the relationship between insecticide resistance and the incidence of DHF.

The level of knowledge of farmers regarding the management of agricultural insecticide resistance, namely, $33 \%$ of subjects have know-

Table 2. Percentage of Knowledge on Insecticide Resistance Management

\begin{tabular}{|c|c|c|c|}
\hline \multirow[t]{2}{*}{ No } & \multirow[t]{2}{*}{ Knowledge Indicators } & \multicolumn{2}{|c|}{ Number } \\
\hline & & Frequency & $\%$ \\
\hline \multirow[t]{6}{*}{1.} & Household Insecticide Resistance & & \\
\hline & Know & 5 & 42 \\
\hline & Not know & 7 & 58 \\
\hline & Agricultural insecticide resistance & & \\
\hline & Know & 4 & 33 \\
\hline & Not know & 8 & 67 \\
\hline \multirow[t]{6}{*}{2.} & Household insecticide resistance signs & & \\
\hline & Know & 5 & 42 \\
\hline & Not know & 7 & 58 \\
\hline & Agricultural insecticide resistance signs & & \\
\hline & Know & 3 & 25 \\
\hline & Not know & 9 & 75 \\
\hline \multirow[t]{6}{*}{3.} & Causes of household insecticide resistance & & \\
\hline & Know & 2 & 25 \\
\hline & Not know & 10 & 75 \\
\hline & Causes of agricultural insecticide resistance & & \\
\hline & Know & 2 & 17 \\
\hline & Not know & 10 & 83 \\
\hline \multirow[t]{6}{*}{4.} & Household insecticide resistance prevention & & \\
\hline & Know & 2 & 25 \\
\hline & Not know & 10 & 75 \\
\hline & Prevention of agricultural insecticide resistance & & \\
\hline & Know & 2 & 17 \\
\hline & Not know & 10 & 83 \\
\hline \multirow[t]{6}{*}{5.} & Impact of improper use of household insecticides & & \\
\hline & Know & 4 & 33 \\
\hline & Not know & 8 & 67 \\
\hline & Impact of improper use of agricultural insecticides & & \\
\hline & Know & 2 & 17 \\
\hline & Not know & 10 & 83 \\
\hline \multirow[t]{6}{*}{6.} & The way to tackle household insecticide resistance & & \\
\hline & Know & - & - \\
\hline & Not know & 12 & 100 \\
\hline & The way to tackle agricultural insecticide resistance & & \\
\hline & Know & 1 & 8 \\
\hline & Not know & 11 & 92 \\
\hline \multirow[t]{6}{*}{7.} & $\begin{array}{l}\text { Knowledge of the relationship between improper use of } \\
\text { household insecticides and the increase in DHF cases }\end{array}$ & & \\
\hline & Know & - & - \\
\hline & Not know & 12 & 100 \\
\hline & $\begin{array}{l}\text { Knowledge of the relationship between inappropriate use } \\
\text { of agricultural insecticides and the increase in DHF cases }\end{array}$ & & \\
\hline & Know & - & - \\
\hline & Not know & 12 & 100 \\
\hline
\end{tabular}


ledge related to the understanding of insecticide resistance. Answers to the interview results with the following details: $25 \%$ of subjects know the signs of resistance, $17 \%$ of subjects know the causes of resistance, $17 \%$ of subjects know how to prevent resistance, $17 \%$ of subjects know the impact of improper use of insecticides, $8 \%$ of subjects know how to overcome insecticide resistance, and none of the subjects had knowledge of

the relationship between agricultural insecticide resistance and the incidence of DHF.

Public knowledge in using household insecticides and agricultural insecticides should be improved, where inadequate knowledge of using insecticides will affect the behavior and actions of the community that are not quite right. From the results of the study, most of the subjects, namely more than $50 \%$ of research subjects, had Table 3. Description of Attitudes in Insecticide Resistance Management

\begin{tabular}{|c|c|c|c|}
\hline \multirow[t]{2}{*}{ No } & \multirow[t]{2}{*}{ Attitude Indicators } & \multicolumn{2}{|c|}{ Number } \\
\hline & & Frequency & $\%$ \\
\hline \multirow[t]{6}{*}{1.} & The subject's attitude about eradicating insects using household insecticides & & \\
\hline & Agree & 9 & 75 \\
\hline & Disagree & 3 & 25 \\
\hline & The subject's attitude regarding insect eradication using agricultural insecticides & & \\
\hline & Agree & 10 & 83 \\
\hline & Disagree & 2 & 17 \\
\hline \multirow[t]{6}{*}{2.} & The subject's attitude about household insecticide safety & & \\
\hline & Agree & 12 & 100 \\
\hline & Disagree & - & - \\
\hline & The attitude of the subject regarding the safety of agricultural insecticides & & \\
\hline & Agree & 12 & 100 \\
\hline & Disagree & - & - \\
\hline \multirow[t]{6}{*}{3.} & $\begin{array}{l}\text { The subject's attitude about household insecticide resistance management infor- } \\
\text { mation }\end{array}$ & & \\
\hline & Agree & 5 & 42 \\
\hline & Disagree & 7 & 58 \\
\hline & $\begin{array}{l}\text { The subject's attitude regarding agricultural insecticide resistance management } \\
\text { information }\end{array}$ & & \\
\hline & ( & 11 & 92 \\
\hline & Disagree & 1 & 8 \\
\hline \multirow[t]{6}{*}{4.} & $\begin{array}{l}\text { The subject's attitude regarding household insecticide resistance management } \\
\text { practices }\end{array}$ & & \\
\hline & Agree & 6 & 50 \\
\hline & Disagree & 6 & 50 \\
\hline & $\begin{array}{l}\text { The subject's attitude regarding agricultural insecticide resistance management } \\
\text { practices }\end{array}$ & & \\
\hline & Agree & 9 & 75 \\
\hline & Disagree & 3 & 25 \\
\hline \multirow[t]{6}{*}{5.} & $\begin{array}{l}\text { The subject's attitude about the countermeasures of household insecticide resist- } \\
\text { ance }\end{array}$ & & \\
\hline & Agree & 9 & 75 \\
\hline & Disagree & 3 & 25 \\
\hline & $\begin{array}{l}\text { The subject's attitude about the countermeasures of agricultural insecticide resist- } \\
\text { ance }\end{array}$ & & \\
\hline & Agree & 12 & 100 \\
\hline & Disagree & - & - \\
\hline \multirow[t]{3}{*}{6.} & The subject's attitude about mixing agricultural insecticides & & \\
\hline & Agree & 7 & 58 \\
\hline & Disagree & 5 & 47 \\
\hline \multirow[t]{3}{*}{7.} & The subject's attitude regarding the use of the insecticide with excessive doses & & \\
\hline & Agree & 7 & 58 \\
\hline & Disagree & 5 & 47 \\
\hline
\end{tabular}


Table 4. Description of Community Actions in Using Insecticides

\begin{tabular}{|c|c|c|c|}
\hline & \multirow[t]{2}{*}{ Action Indicators } & \multicolumn{2}{|c|}{ Number } \\
\hline & & Fre- & $\%$ \\
\hline \multirow[t]{6}{*}{1.} & The way to choose the type of household insecticide & & \\
\hline & Choose the type of insecticide that works & 12 & 100 \\
\hline & The way to select the type of agricultural insecticide & & \\
\hline & Yes, I choose what works, if it doesn't work, I change to another type & 8 & 58 \\
\hline & I chose the one suggested from the farm officer & 2 & 16,5 \\
\hline & I chose the one suggested from the farm shop & 2 & 16.5 \\
\hline \multirow[t]{7}{*}{2.} & Frequency of household insecticide use & & \\
\hline & Once a day & 5 & 42 \\
\hline & Two times a day nap time, and night & 2 & 16 \\
\hline & Yes, not sure, only use it if there are mosquitoes & 5 & 42 \\
\hline & Frequency of use of agricultural insecticides & & \\
\hline & Yes, not necessarily, but usually two times a year, because once year the harvest is two times & 8 & 67 \\
\hline & If only there is a planthopper attack & 4 & 33 \\
\hline \multirow[t]{8}{*}{3.} & Duration of use of household insecticides & & \\
\hline & About 15 years or more & 7 & 58 \\
\hline & Approximately 10 years & 4 & 33 \\
\hline & Less than 5 years & 1 & 8 \\
\hline & Duration of use of agricultural insecticides & & \\
\hline & It's been a long time, miss, more than 10 years & 9 & 75 \\
\hline & Yes, about 5 years, & 2 & 17 \\
\hline & Just 3 years ago, & 1 & 8 \\
\hline \multirow[t]{7}{*}{4.} & Change of rotation of household insecticides & & \\
\hline & Yes, I have been using mosquito repellent since a long time ago because I used to use it & 8 & 67 \\
\hline & $\begin{array}{l}\text { Yes, if there is no mosquito repellent in the shop, I have changed it to another one, but yes, I } \\
\text { don't replace it regularly }\end{array}$ & 3 & 25 \\
\hline & If there is a promo I sometimes buy it & 1 & 8 \\
\hline & Rotation of changing the type of agricultural insecticide based on how it works & & \\
\hline & Yes, you have always used it, miss, because it's good for killing planthoppers & 5 & 42 \\
\hline & Yes, sometimes it changes if the medicine doesn't work anymore & 7 & 58 \\
\hline \multirow[t]{7}{*}{5.} & Reading and following instructions for household insecticide use & & \\
\hline & I never read the instructions for use & 10 & 83 \\
\hline & I read sometimes when I first bought brand "A" & 2 & 17 \\
\hline & Reading and following directions for using agricultural insecticides & & \\
\hline & I never read the instructions for use & 5 & 42 \\
\hline & I sometimes read and follow the instructions for use & 3 & 25 \\
\hline & Yes I read the manual use book before using it & 4 & 33 \\
\hline \multirow[t]{6}{*}{6.} & Time of household insecticide application & & \\
\hline & At night & 5 & 42 \\
\hline & During the day nap time and at night & 2 & 16 \\
\hline & $\begin{array}{l}\text { Yes, if there are mosquitoes in the morning, I will use it in the morning, if there are mosqui- } \\
\text { toes in the afternoon, use it during the day. }\end{array}$ & 5 & 42 \\
\hline & Time of application of agricultural insecticides & & \\
\hline & $\begin{array}{l}\text { Spraying time is in the morning, because advice from agricultural officers should be done in } \\
\text { the morning }\end{array}$ & 12 & 100 \\
\hline \multirow[t]{5}{*}{7.} & Avoiding the use of one class of household insecticides for pre-adult and adult targets & & \\
\hline & Keeping using mosquito repellent & 3 & 25 \\
\hline & For mosquitoes I use mosquito repellent, but for larvae I use abate. & 9 & 75 \\
\hline & Avoiding the use of one class of agricultural insecticides for pre-adult and adult targets & & \\
\hline & Yes, I don't know, the insect is an adult or a child, I still use the same insecticide. & 12 & 100 \\
\hline \multirow[t]{3}{*}{8.} & Dosage for use of agricultural insecticides & & \\
\hline & I use the size of the cap of the medicine bottle & 9 & 75 \\
\hline & If the size is estimated & 3 & 25 \\
\hline \multirow[t]{3}{*}{9.} & Retailing of agricultural insecticides & & \\
\hline & Yes, I have done insecticide retailing, because my friend said it works with other types & 5 & 42 \\
\hline & Yes advice from the agricultural officer & 7 & 58 \\
\hline
\end{tabular}


insufficient knowledge of household insecticide resistance management. Ambarawa Puskesmas officers who handle the DHF program confirmed that the community has insufficient knowledge of household insecticide resistance management. Increasing public knowledge will be more effective with the participation of the community by following outreach activities from health workers, the community will better understand how to use the right insecticide rather than reading the instructions for using insecticide from the insecticide packaging label. This research is in accordance with Musfirah's research (2017) which states that public knowledge about insecticide resistance management is still lacking and needs to be improved to prevent insecticides used by resistance. But this study is not in accordance with the results of Wigati's (2012) study regarding knowledge of the community regarding the procedures for using insecticides, dosages, their effects on insects and the active ingredients used, which states that most people have moderate knowledge.

Additional interviews with Agricultural Extension Officers in Ambarawa District, obtained information that farmers have insufficient knowledge of resistance management. Increasing farmers' knowledge will be more effective if farmers participate in extension activities from agricultural officers, so that farmers will better understand how to use appropriate insecticides, rather than reading instructions for use of insecticides from insecticide packaging labels themselves. Farmers' knowledge of resistance management is still low, because it does not comply with the guidelines for insecticide resistance management issued by the Ministry of Agriculture. The results of this study are in line with Suryani \& Pratamasari, (2020) which states that most farmers, namely more than $50 \%$ of farmers, have insufficient knowledge in insecticide resistance management practices, insufficient knowledge causes farmer behavior in the practice of using insecticides as desired without thinking about the consequences or the effects of improper use of insecticides.

\section{Community Attitudes in Insecticide Resistance Management}

The results of the study regarding the attitude of the community using household insecticides, namely, the attitude towards eradicating insects using chemical insecticides $75 \%$ of the subjects agreed, $100 \%$ of the subjects agreed about the safety of insecticides, $42 \%$ of the subjects agreed to receive information on insecticide resistance management, $50 \%$ of the subjects agreed to practice resistance management, and $75 \%$ of subjects agreed to control insecticide resistance.

The attitude of farmers in agricultural insecticide management is an attitude towards eradicating insects using chemical insecticides $83 \%$ of subjects agree, $100 \%$ of subjects agree on the safety of insecticides, $92 \%$ of subjects agree to receive information on insecticide resistance management, $75 \%$ of subjects agree to practice resistance management, $58 \%$ of subjects agree did the mixing of insecticides without guidelines, 58\% of subjects agreed to use an excessive dose of insecticide, and $75 \%$ of subjects agreed to control insecticide resistance.

The public has a bad attitude in the management of insecticide resistance due to a lack of awareness of the impact of improper use of insecticides. The results of the study stated that $50 \%$ of the subjects agreed that resistance management practices were carried out but it was not in accordance with the behavior, because less than $50 \%$ of the subjects practiced insecticide resistance management. Public Health Center officers in Ambarawa who handle the DHF program confirmed that positive attitudes from the community are not always followed by positive behavior.

The results of the research on farmers stated that most farmers agreed that resistance management practices were carried out but they were not in accordance with their behavior, because only a small proportion of farmers, namely less than $50 \%$ of farmers, practiced insecticide resistance management. The Agricultural Extension Officer in Ambarawa District confirmed that the positive attitude of the community is not always followed by positive behavior. The results of this study are not in accordance with the results of research by Suryani \& Pratamasari (2020) which states that attitudes are related to behavior. Because the internal factors of farmers in Ambarawa district that are most influential are the fulfillment of their needs and business constraints, the intense disturbance of pests (plant pests) raises concerns for farmers, thus encouraging farmers to act impulsively in the application of insecticides to avoid crop failure.

\section{Community Actions in Insecticide Resistance Management}

The results of research on community action in household use of insecticides, namely, how to choose the type of insecticide $100 \%$ of the subjects chose a potent insecticide, $42 \%$ of the subjects used an insecticide once a day, $16 \%$ of the subjects used an insecticide twice a day during the day and night, $42 \%$ of the subjects used it. in- 
secticide in the presence of mosquitoes only, $58 \%$ used the same insecticide for more than 15 years, $33 \%$ of subjects used the same insecticide for less than 10 years, $17 \%$ of subjects used the same insecticide for less than 5 years, $100 \%$ of subjects did not apply the same insecticide insecticide work, $83 \%$ of subjects never read the instructions for use, $17 \%$ of subjects read the instructions for use sometimes, $42 \%$ of subjects when applying insecticides at night, $16 \%$ of subjects when applying insecticides during the day and night, $42 \%$ of the time subjects the application of insecticides when there are mosquitoes, and $75 \%$ of subjects avoid using one class of insect ecticides for pre-adult and adult targets.

Based on the results of research with farmer research subjects, namely, how to choose the type of insecticide $58 \%$ of the subjects chose a potent insecticide, $16.5 \%$ of the subjects chose on the advice of agricultural officers, $16.5 \%$ of subjects chose on the advice of the seller, the frequency of insecticide use was $67 \%$ of the subject one year 2 times of use, there were $33 \%$ of subjects used when there was a pest / insect attack, 75\% of subjects used the same insecticide for more than 10 years, $17 \%$ of subjects used the same insecticide for less than 5 years, $8 \%$ of subjects used the same insecticide less from 3 years, $100 \%$ of subjects did not apply alternation rotation based on the correct way of working of the insecticide, $75 \%$ of subjects determined the dose using the dose of the drug bottle cap, $25 \%$ of the subjects measured the insecticide dose approximate, $42 \%$ of the subjects carried out the retail on the advice of friends, $58 \%$ of subjects made retail on the advice of agricultural officers, $42 \%$ of subjects never read the instructions for use, $25 \%$ of subjects sometimes reading, $33 \%$ of subjects read the instructions for use, $100 \%$ of subjects sprayed in the morning, and $100 \%$ of subjects did not avoid using one class of insecticides for pre-adult and adult targets.

The types of active ingredients used, the duration of use, and the frequency of use, which are almost entirely carried out every time a DHF case occurs in each year are factors that are thought to increase $A$ e. aegypti resistance. The selection of insecticides is needed to ensure that the chemicals used are effective in eradicating the DHF vector (Hardjanti et al, 2015). Insecticide resistance management practices are classified as bad, because not all of the subjects studied applied resistance prevention practices according to the guidelines for using insecticides in vector hedge issued by the Indonesian Ministry of Health in 2012. The bad behavior of using chemical insec- ticides causes the incidence of insecticide resistance, which results in the rapid development of the DHF vector. The public health center officer in Ambarawa who handles the DHF program stated that people's behavior in the use of household insecticides does not always follow the guidelines for insecticide resistance management. When the insecticide used is no longer effective, people always buy another effective brand of insecticide. The results of this study are supported by the results of research by Cimi (2019) which states that the reason people choose and replace the type of insecticide is based on the effectiveness of the insecticide regardless of the ingredients or content and the way the household insecticides work. There are $58 \%$ of research subjects stated that they used insecticide with the same brand for more than 10 years. This research is also supported by the results of research by Kusumastuti (2014) in Pangandaran Village, which shows that $59 \%$ of the community uses the same household insecticide for about 10 years. This can lead to the incidence of insecticide resistance, because it takes a long time to use insecticides without rotating insecticide changes by working with different insecticides.

The results of research in Matowo et al., (2020) that insecticide resistance is thought to be due to the use of insecticides in agriculture. The type of active insecticide used, the duration of use, and the frequency of use every time an insect attack occurs in the farm is a factor that can cause insecticide resistance to insects including mosquito vector. Most of the agricultural insecticides used in the study area contain the active ingredients deltamethrin, cypermethrin, and carbosulfan. From the overall actions of farmers in using insecticides, it can be seen that most farmers do not apply the Guidelines for the Use of Insecticides (Pesticides) in Vector Control (Ministry of Health, 2019). There are $75 \%$ of farmers using insecticides with the same insecticide for more than 10 years. There are $75 \%$ of the subjects measuring the insecticide dose only approximate. The use of insecticides with an inappropriate dosage and the duration of using insecticides with the same ingredients or working method without rotating can cause the insecticide used to be resistant. The results of Isfanda's (2017) study show that the development of resistance depends on the frequency of insecticide use and the duration of application over five years. Agricultural Extension Officers in Ambarawa District stated that most farmers, namely more than $50 \%$ of farmers, do not know insecticide resistance, but farmers are always careful in applying insecticides for fear 
of dying plants. From the research results, most of the farmers, namely more than $50 \%$ of farmers have a positive attitude but it is not implemented because they are afraid of crop failure.

\section{Insecticide Resistance}

According to WHO (2012) insecticide resistance is characterized by a decrease in insecticide effectiveness and vector mortality of less than $80 \%$. From the results of research related to household insecticides, $75 \%$ of the people felt a decrease in the effectiveness of household insecticides. This is because the behavior of the community regarding household insecticide resistance management is still classified as bad, because not all people follow the guidelines for insecticide management. .

From the results of research related to agricultural insecticides, $67 \%$ of farmers felt a decrease in the effectiveness of agricultural insecticides. This is because the behavior of farmers regarding the management practices of agricultural insecticide resistance is classified as bad because not all farmers follow the guidelines for insecticide management. The incidence of insecticide resistance in Ae. aegypti is caused by the use of insecticides continuously and for a long time (Sundari \& Orbayinah, 2010; Chareonviriyaphap et al., 2013)

\section{CONCLUSION}

Based on the results of research on behavior of household insecticide use and agriculture in Ambarawa District, it can be concluded that more than $50 \%$ of the community does not have sufficient knowledge regarding insecticide resistance management. Community and farmer behavior in the practice of household insecticide use and agriculture is poor. because less than $50 \%$ of research subjects do not apply insecticide resistance management, so that it can cause resistance to the Aedes aegypti vector. So it is hoped that the community can increase knowledge about insecticide resistance management, which is then applied so that it can overcome insecticide resistance.

\section{REFERENCES}

Chareonviriyaphap, T., Bangs, M.J., Suwonkerd, W., Kongmee, M., Corbel, V \& NgoenKlan, R. 2013. Review of Insecticide Resistance and Behavioral Avoidance of Vectors of Human Diseases in Thailand. Parasites and Vectors, 6: 280. https://doi. org/10.1186/1756-3305-6-280

Data Center and Information from the Ministry of Health of the Republic of Indonesia.
2017. InfoDatin-Situasi-Demam-BerdarahDengue. Jakarta: Kementerian Kesehatan RI. https://pusdatin.kemkes.go.id/download.php?file $=$ download $/$ pusdatin $/$ infodatin/InfoDatin-Situasi-Demam-Berdarah-Dengue.pdf

Farajollahi, A., Healy, S. P., Clark, G. G., \& Fonseca, D. M. 2014. Insecticide Resistance Status of United States Populations of Aedes albopictus and Mechanisms Involved. Plos One, 9 (7): 1-10. https://doi. org/10.1371/journal.pone.0101992

Gatton, M.L., Chitnis, N., Churcher, T., Donnelly, M.J., Ghani, A.C., Godfray, H.C.J., Gould, F., Hasting, I., Marshall, J., Ranson, H., Rowland, M., Shaman, S.W. \& Lindsay, J. 2013. The Importance of Mosquito Behavioural Adaptations to Malaria Control in Africa. Evolution - International Journal of Organic Evolution, 6 (7): 12181230. https://doi.org/10.1111/evo.12063

Joharina, A.S. \& Alfiah, S. 2012. Descriptive Analysis of Household Insecticide in Community. Vektora: Jurnal Vektor dan Reservoir Penyakit, 4 (1): 23-33. https://media. neliti.com/media/publications/125905-IDnone.pdf

Kusumastuti, N. H. Penggunaan Insektisida Rumah Tangga Antinyamuk di Desa Pangandaran, Kabupaten Pangandaran. Widyariset, 17 (3): 417-424. http://dx.doi.org/10.14203/widyariset.17.3.2014.417-424

Kusumawati, N. \& Sukendra, D. 2020. Spasiotemporal Demam Berdarah Dengue berdasarkan House Index, Kepadatan Penduduk dan Kepadatan Rumah. HIGEIA (Journal of Public Health Research and Development), 4 (2): 168-177. https://doi. org/10.15294/higeia.v4i2.32507

Hardjanti, A., Indrawati, I., Donanti, E., Wibowo, H., Nasir, Z. 2015. Detection of Insecticide Resistance in Aedes Aegypti to Organophosphate in Pulogadung. Makara Journal of Health Research, 19 (3): 117120. http://journal.ui.ac.id/index.php/ health/article/view/5563

Mathieu, R. B., Pocquet, N., Riaz, M., David, J., \& Chandre, F. 2012. Insecticide Resistance in the Dengue Vector Aedes aegypti from Martinique: Distribution , Mechanisms and Relations with Environmental Factors. Plos One, 7 (2): e30989. https://doi. org/10.1371/journal.pone.0030989

Matowo, N.S., Tanner, M., Munhenga, G., et al. 2020. Patterns of Pesticide Usage 
in Agriculture in Rural Tanzania Call for Integrating Agricultural and Public Health Practices in Managing InsecticideResistance in Malaria Vectors. Malaria Journal, 19: 257. https://doi.org/10.1186/ s12936-020-03331-4

Musfirah. 2017. Pengendalian Kimia dan Resistensi Vektor Anopheles Dewasa pada Kawasan Endemis Malaria di Dunia. Kes mas: Jurnal Fakultas Kesehatan Masyarakat, 11 (1): 46-51. http://journal.uad.ac.id/index.php/KesMas/article/view/5855

Pinto, J., Palomino, M., Mendoza-Uribe, L., Sinti, C., Liebman, K.A., \& Lenhart, A. 2019. Susceptibility to Insecticides and Resistance Mechanisms in Three Populations of Aedes aegypti from Peru. Parasites and Vectors, 12: 494. https://doi.org/10.1186/ s13071-019-3739-6

Riyadi, S. 2017. Penggunaan Insektisida dan Status Kerentanan Nyamuk Aedes aegypti di Daerah Endemis di Kabupaten Purbalingga. Jurnal Berita Kedokteran Masyarakat, 33 (10): 459-466. https://jurnal.ugm.ac.id/ bkm/article/view/25941/20557

Sugiyono. 2016. Metode Penelitian Pendidikan: Pendekatan Kuantitatif, Kualitatif, dan R\&D. Alfabeta. http://cvalfabeta.com/product/ metode-penelitian-kuantitatif-kualitatifdan-rd-mpkk/

Sukendra, D.M., Santik, Y., Wahyono, B., Siyam, N., \& Indrawati, F. 2020. The Influence of Vegetation and House Index on Male Mosquitoes DHF Vector Abundance on Kawengen Sub-District. Unnes Journal of Public Health, 9 (1), 64-70. https://doi. org/10.15294/ujph.v9i1.34714

Sunaryo. 2015. Description of Aplication Household Insecticide in DHF Endemic Area. Jurnal Balaba, 11 (1): 9-14. https://doi. org/10.22435/balaba.v11i1.4149.9-14

Sundari, S., \& Orbayinah, S. 2010. Deteksi Resistensi Insektisida Nyamuk Aedes Aegypti Berdasarkan Aktifitas Enzim Glutation STransferase. Mutiara Medika: Jurnal Kedokteran dan Kesehatan, 10 (1), 62 - 67. https:// doi.org/10.18196/mmjkk.v10i1.1563

Suryani, D., \& Pratamasari, R. 2020. Perilaku Petani Padi dalam Penggunaan Pestisida di Desa Mandalahurip Kecamatan Jatiwaras Kabupaten Tasikmalaya. Jurnal Kesehatan (Window of Health), 3 (2): 95-103. https://doi.org/10.33368/woh.v0i0.285

WHO. 2012. Global Strategy for Dengue Prevention and Control. Geneva: World Health Organzation. https://www.who.int/denguecontrol/9789241504034/en/

Widiarti. 2015. Peta Resistensi Vektor Demam Berdarah Dengue Aedes aegypti terhadap Insektisida Kelompok (Organofosfat, Karbamat, dan Pyrethdiroid) di Provinsi Jawa Tengah dan Daerah Istimewa Yogyakarta. Buletin Penelitian Kesehatan. 40 (1): 31-38. http://ejournal.litbang.kemkes.go.id/index.php/BPK/article/view/54

Cahyati, W.H. \& Fitriani, L. 2020. Deteksi Resistensi Aedes aegypti terhadap Sipermetrin Menggunakan Teknik Polymerase Chain Reaction (PCR) di Ambarawa Kabupaten Semarang. Unnes Journal of Public Health, 9 (1): 71-77. https://doi.org/10.15294/ ujph.v9i1.34868

Wigati, L. 2012. Hubungan Karakteristik, Pengetahuan, dan Sikap dengan Perilaku Masyarakat dalam Penggunaan Anti Nyamuk di Kelurahan Kutowaringin. Buletin Penelitian Kesehatan, 40(3): 140-141. http:// ejournal.litbang.kemkes.go.id/index.php/ BPK/article/view/2895 